\title{
Direct In Vitro Shoot Regeneration from Spindle Leaf Roll Segments of Sugarcane
}

\author{
Jashandeep Singh Gill and Jagdeep Singh Sandhu*
}

School of Agricultural Biotechnology, Punjab Agricultural University, Ludhiana, Punjab, India

*Corresponding author: js_sandhu@pau.edu (ORCID ID: (0000-0003-3743-2985)

Paper No. 913

Received: $11-06-2021$

Revised: 07-08-2021

Accepted: 02-09-2021

\begin{abstract}
The spindle leaf roll segments of sugarcane cultivar Co 238 were cultured in vitro for shoot regeneration. Cultured spindles exhibited unwhorling after 5 to 10 days of incubation followed by direct shoot regeneration without callus phase. Shoot initiation was observed in a cluster of 2-3 shoots after the third week of incubation. Data was recorded for the number of shoots, shoot length, rooting frequency, and root length. Maximum of $7.68 \pm 1.26$ shoots with mean shoot length of $8.13 \pm 1.87 \mathrm{~cm}, 100 \%$ root induction frequency, and mean root length of $3.89 \mathrm{~cm}$ were recorded. This study demonstrates the development of a reliable method for sugarcane improvement and can be used for micropropagation and genetic engineering of Co 238 cultivar.
\end{abstract}

\section{HIGHLIGHTS}

(0 Direct shoot regeneration without callus phase with shoot and root induction on the same media.

- A reliable method was developed for sugarcane improvement and can be used for micropropagation.

Keywords: Sugarcane, direct shoot regeneration, without callus phase

Sugarcane is a commercially important sugar crop conventionally propagated vegetatively. The major drawback of vegetative propagation is a low rate of seed multiplication leading to the slow spread of new, improved cultivars. Rapid multiplication can be achieved through in vitro manipulations. In sugarcane, shoot regeneration has been obtained through indirect (Oo et al. 2018, Zamir et al. 2012) and direct organogenesis (Tesfa and Ftwi 2018). Amongst these, direct organogenesis is advantageous as it leads to the production of shoots without intervening callus phase (Desai et al. 2004). The callus induction in a highly polyploid crop like sugarcane can cause somaclonal variations (Sobhakumari et al. 2012). Direct shoot regeneration has been reported from spindle leaf roll segments (Gill et al. 2006), nodal explants (Cheema and Hussain 2004), leaf whorls (Lakshmanan et al. 2002), apical meristem (Redae and Ambaye 2018) of sugarcane.
Direct shoot regeneration in sugarcane has been obtained from single epidermal cells (Kaur and Sandhu 2015), adventive embryos (Sandhu et al. 2016), and somatic embryos (Kalunke et al. 2009). Direct shoot regeneration has also been obtained from cortical cells of coriander (Zee 1981), hypocotyl cells of carrot (Wetherell 1984), mesophyll cells of alfalfa (Dijak and Brown 1987), endosperm cells of higher plants (Vasil and Vasil 1972), and parenchyma cells of orchard grass (Conger et al. 1983). The shoots regenerated through direct shoot regeneration usually have a unicellular origins pointing to type multiplication of plants (Shah et al., 2009).

In present study, we attempted direct shoot

How to cite this article: Gill, J.S. and Sandhu, J.S. 2021. Direct In Vitro Shoot Regeneration from Spindle Leaf Roll Segments of Sugarcane. IJAEB, 14(03): 313-317.

Source of Support: None; Conflict of Interest: None (9) क्ष 
regeneration in local sugarcane cultivar Co 238 that is mid-late maturing, tall, good ratooner with the objective that direct shoot regeneration protocol could be used for the improvement of cultivar through genetic engineering and mass multiplication of plant material.

\section{MATERIALS AND METHODS}

\section{Plant material}

The plant material comprised of local sugarcane cultivar Co 238 taken from Regional Research Station, Kapurthala during the July-August (formative phase) 2019. The spindle leaf roll segments were prepared from the top apical cuttings. The in vitro experiments were carried out in Tissue culture and Genetic Transformation Laboratory, School of Agricultural Biotechnology, Punjab Agricultural University, Ludhiana.

\section{Explant preparation}

The spindle leaf roll segments excised from fieldgrown healthy sugarcane were used as explant. The explants were thoroughly washed for 10 minutes under running tap water. Then explants were washed with Teepol solution and $1 \%$ Tween-20 for $5 \mathrm{~min}$, then rinsed with sterile distilled water to remove the detergent. Subsequently, they were treated with $1 \%$ Bavistin by shaking on a rotary shaker (New Brunswick Scientific, USA) at $150 \mathrm{rpm}$ for 30-60 minutes and $0.1 \% \mathrm{HgCl}_{2}$ for 9-10 min to the method described by Sandhu et al. (2016). This was followed by three items of washing with sterile distilled water.

\section{Shoot regeneration}

The shoot regeneration was induced on MS media supplemented with $5 \mathrm{mg} / \mathrm{l} \mathrm{NAA}+0.5 \mathrm{mg} / \mathrm{l}$ Kinetin + $30 \mathrm{~g} / \mathrm{l}$ sucrose $+8 \mathrm{~g} / \mathrm{l}$ agar designated as M1. Second shoot regeneration media, namely $\mathrm{M} 2$ contained MS $+2 \mathrm{mg} / \mathrm{L} \mathrm{NAA}+0.5 \mathrm{mg} / \mathrm{L}$ Kinetin $+30 \mathrm{~g} / \mathrm{l}$ sucrose $+8 \mathrm{~g} / \mathrm{l}$ agar. Third media i.e. M3 contained MS supplemented with $7 \mathrm{mg} / \mathrm{l} \mathrm{NAA}+1 \mathrm{mg} / \mathrm{l}$ Kinetin $+30 \mathrm{~g} / \mathrm{l}$ sucrose $+8 \mathrm{~g} / \mathrm{l}$ agar. Root induction was carried on two media designated as M1 and M4. MS containing $0.5 \mathrm{mg} / \mathrm{L}$ IAA and $0.5 \mathrm{mg} / \mathrm{L} \mathrm{IBA}$ and $0.5 \mathrm{mg} / \mathrm{L} \mathrm{BAP}$ and $30 \mathrm{~g} / \mathrm{l}$ sucrose and $8 \mathrm{~g} / \mathrm{l}$ agar was designated as M4. Cultures were incubated in a growth room at $25 \pm 2{ }^{\circ} \mathrm{C}$ under $16 / 8 \mathrm{~h}$ light/dark photoperiod.

\section{Transfer of regenerated plants to soil and data analysis}

The shoot clumps were hardened on moist cotton soaked in water and kept in an incubation room for 3-5 days at $25 \pm 2{ }^{\circ} \mathrm{C}$ under $16 / 8 \mathrm{~h}$ light/ dark photoperiod. After hardening, clumps were separated into individual plantlets and were transferred to plastic bags containing soil. The plants were watered regularly. The shoot length, root length, and no. shoots per explant were analyzed using R software (ANOVA test).

\section{RESULTS AND DISCUSSION}

\section{Direct shoot regeneration}

The leaf roll segments showed unwhorling after 5 to 10 days of incubation. The unwhorling was observed after the sixth day of incubation on M1 medium, after the ninth day of incubation on M2 medium, and after the seventh day of incubation on M3 medium. The direct shoot regeneration was detected from the cut ends of leaf tissue after the third week of incubation in clusters of 2-3 shoots without the callus phase (Fig. 1A). The shoots were excised from the explants and sub-cultured on the same media for another passage leading to shooting proliferation after 2 weeks of incubation (Fig. 1B). After six weeks of culture initiation, data on the number of shoots per explant, length of shoots were recorded, and after hardening the plantlets were transferred to soil (Fig. 1C, D). The number of shoots per explant was maximum on M1 (7.68 \pm 1.26) as compared to M2 (6.04 \pm 1.05$)$ and M3 (4.5 \pm 0.79). Maximum mean shoot length $8.13 \pm 1.87 \mathrm{~cm}$ was recorded on M1 medium, followed by $6.19 \pm$ $1.23 \mathrm{~cm}$ on M2 and $4.78 \pm 0.94 \mathrm{~cm}$ on M3 (Fig. 2). Redae and Ambaye (2018) obtained 10.667 number of shoots per explant on MS media containing 2.0 $\mathrm{mg} / \mathrm{l} \mathrm{BAP}$ and $1.0 \mathrm{mg} / \mathrm{l} \mathrm{NAA}$. They also recorded a maximum shoot length of $8.4 \pm 0.008 \mathrm{~cm}$ on 1.5 $\mathrm{mg} / \mathrm{l} \mathrm{BAP}$ and $0.5 \mathrm{mg} / \mathrm{l}$ kinetin. Tesfa and Ftwi (2018) observed $10.73 \pm 0.35$ mean a number of shoots per explant on BAP $2 \mathrm{mg} / \mathrm{l}$ and kinetin 1.5 $\mathrm{mg} / \mathrm{l}$ and maximum shoot length of $3.77 \pm 0.40 \mathrm{~cm}$ on $2 \mathrm{mg} / \mathrm{l}$ BAP and $1.5 \mathrm{mg} / \mathrm{l}$ kinetin. In our study, 

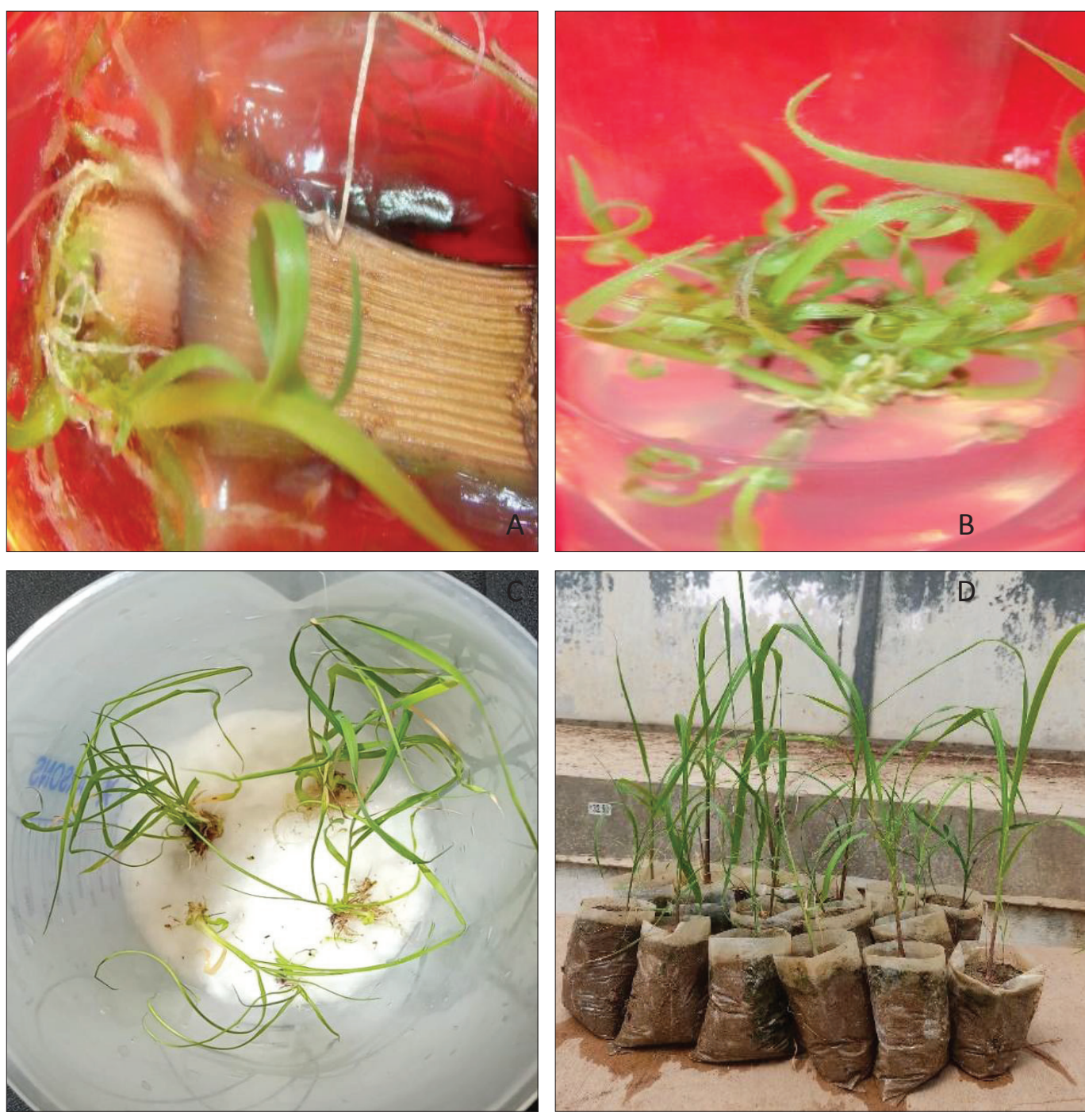

Fig. 1: Direct shoot regeneration in sugarcane (A) Direct shoot regeneration (B) Shoot proliferation (C) Hardening of plantlets (D) Transfer of plantlets to soil

the number of shoots per explants were lesser than these studies. The main differences pertain to the absence of BAP in shoot regeneration media in our study; on the contrary, we used Kinetin. Kinetin is involved in the uninuclear division of cells (Miller et al. 1961), whereas BAP leads to the cell cycle participating in cellular division. In addition, BAP contains $\mathrm{NO}_{3}^{-}$nitrogen and a $\mathrm{NO}_{3}^{-}$to $\mathrm{NH}_{4}^{+}$that affects the plant growth activity. In contrast, NAA in combination with other hormones, promotes shoot and root regeneration in parallel, as observed in our study. It was interesting to note that maximum mean shoot length was obtained in this study as compared to other studies. It can be concluded that direct shoot regeneration is affected by the nature of genotype and the optimum concentration of growth regulators.

\section{Root induction}

The elongated shoots clumps were then rooted on M1 and M4 media. Roots were observed after two weeks of incubation. The rooting percentage was maximum on M1 (100 \%) followed by M4 (96.43\%). The maximum root length of $3.89 \mathrm{~cm}$ was recorded on M1 and $2.9 \mathrm{~cm}$ on M4 (Fig. 3). Tesfa and Ftwi (2018) obtained rooting of $100 \%$ as well as root length of $2.21 \mathrm{~cm}$ in half-strength MS with $5 \mathrm{mg} / \mathrm{l}$ NAA as compared to 3 and $7 \mathrm{mg} / \mathrm{l}$ NAA. In contrast, Redae and Ambaye (2018) obtained a maximum root length of $5.06 \mathrm{~cm}$ on half MS with $2 \mathrm{mg} / 1 \mathrm{NAA}$. The role of NAA for root induction in sugarcane has been highlighted by Tesfa and Ftwi (2018) and Redae and Ambaye (2018). Gill et al. (2006) observed that a lower concentration of NAA (less than $5.0 \mathrm{mg}$ 


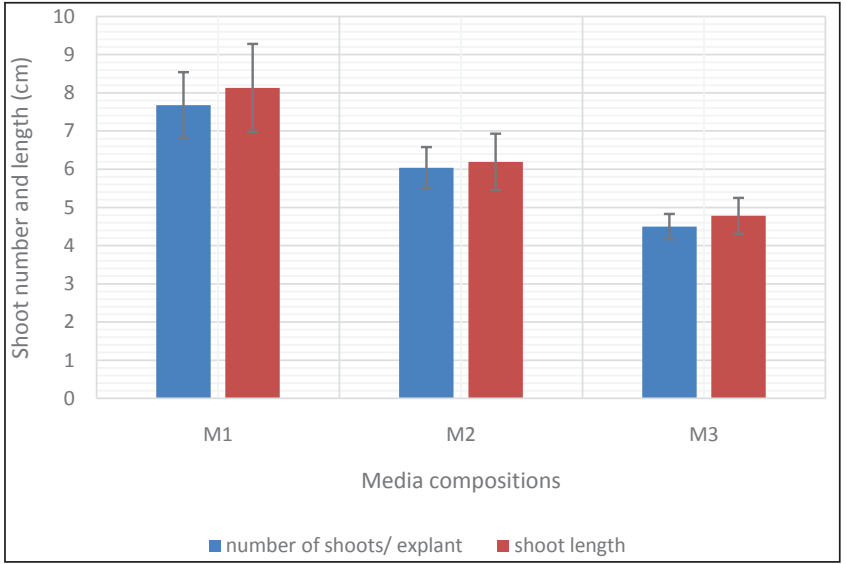

Fig. 2: Effect of media on no. of shoots per explant, shoot length

/l) induced rhizogenesis, and a higher concentration of NAA was not conducive for root induction. It can be concluded that NAA alone or in combination plays a vital role in root induction in sugarcane.

\section{CONCLUSION}

In present study direct regeneration was observed from spindle leaf roll segments without callus phase. The shoot proliferation occurred in clusters, and roots were induced simultaneously. This study demonstrates the development of a reliable method for sugarcane improvement and can be used for micropropagation and genetic engineering of $\mathrm{Co}$ 238 cultivar.

\section{ACKNOWLEDGMENTS}

The authors thankfully acknowledge the School of Agricultural Biotechnology, Punjab Agricultural University, Ludhiana, for providing financial support for researching direct regeneration from spindle leaf roll segments of sugarcane.

\section{REFERENCES}

Cheema, K.L. and Hussain, M. 2004. Micropropagation of Sugarcane Through Apical Bud and Axillary Bud. Int. J. Agri. Biol., 6: 257-259

Conger, B.V., Hanning, G.E., Gray, D.J. and McDaniel, J.K. 1983. Direct embryogenesis from mesophyll cells of orchard grass. Sci., 221: 850-851.

Dijak, M. and Brown, D.C.W. 1987. Patterns of direct and indirect embryogenesis from mesophyll protoplasts of Medicago sativa. Plant Cell Tiss. Organ Cult., 9: 121-130.

Desai, N.S., Suprasanna, P. and Bapat, V.A. 2004. Simple and reproducible protocol for direct somatic embryogenesis from cultured immature inflorescence segments of sugarcane (Saccharum spp.). Curr. Sci., 87: 764-768.

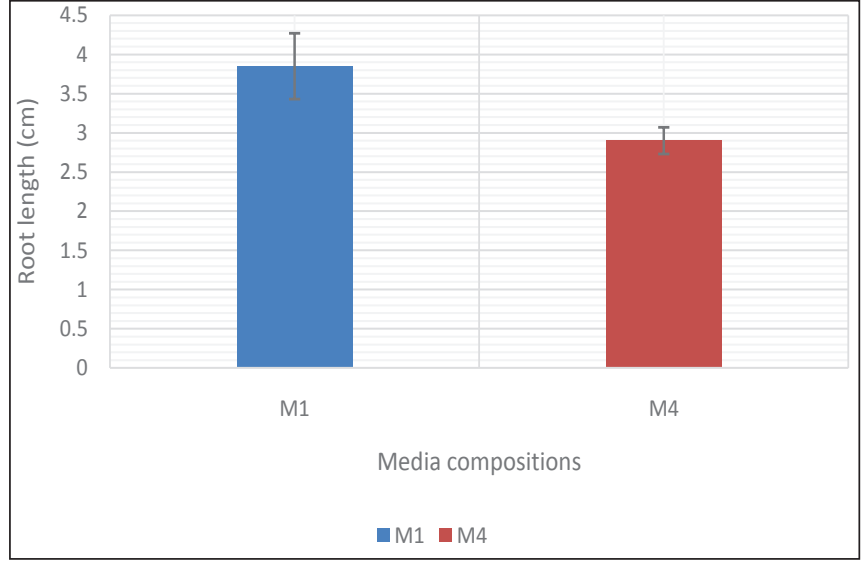

Fig. 3: Effect of media on root length

Gill, R., Malhotra, P.K. and Gosal, S.S. 2005. Direct plant regeneration from cultured young leaf segments of sugarcane. Plant Cell Tiss. Organ Cult., 84: 227-231.

Kalunke, R.M., Kolge, A.M., Babu, K.H. and Prasad, D.T. 2009. Agrobacterium mediated transformation of sugarcane for borer resistance using Cry $1 \mathrm{Aa} 3$ gene and one step regeneration of transgenic plants. Sugar Tech., 11:355-359.

Kaur, A. and Sandhu, J.S. 2015. High throughput in vitro micropropagation of sugarcane (Saccharum officinarum L.) from spindle leaf roll segments: Cost analysis for agribusiness industry. Plant Cell Tiss. Organ Cult., 120:339-350.

Lakshmanan, P., Geijskes, R.J., Elliott, A.R., Wang, L.F., McKeon, M.G., Swain, R.S., Borg, Z., Berding, N., Grof, C.P.L., Smith, G.R. 2002. A genotype-independent in vitro method for rapid, high frequency direct regeneration of sugarcane (Saccharum spp.). Proc Aust Soc for Biochemistry and Molecular Biology Conf, Sydney, Australia Pos-Wed-128.

Miller, C.O. 1961. Kinetin relates compounds in plant growth. Annu. Rev. Plant Physiol., 12: 395-408.

Oo, K.T., Htwe, M.M. and San, N.N. 2018. In vitro Regeneration of Sugarcane (Saccharum officinarum) Varieties GUI 11 and PMA 96/48. J. Sci. Innov. Res., 7: 7-11.

Redae, M.H. and Ambaye, T.G. 2018. In vitro propagation of sugarcane (Saccharum officinarum) variety C86-165 through apical meristem. Biocatal. Agric. Biotechnol., 14: 228-234.

Sandhu, J.S., Kaur, M., Kaur, A. and Kalia, A. 2016. Single step direct transgenic plant regeneration from adventive embryos of agro-infected sugarcane (Saccharum spp.) spindle leaf roll segments with assured genetic fidelity. Plant Cell Tiss. Organ Cult., 125: 149-162

Shah, A.H., Rashid, N., Haider, M.S., Saleem, F., Tahir, M. and Iqbal, J. 2009. An efficient short and cost effective regeneration system for transformation studies of sugarcane (Saccharum officinarum L.). Pak. J. Bot., 42: 609614.

Sobhakumari, V.P. 2012. Assessment of somaclonal variation in sugarcane. African J. Biotechnol., 11: 15303-309. 
Tesfa, M. and Ftwi, M. 2018. In Vitro Plant Regeneration of Sugarcane (Saccharum spp.) Variety Inoculated Under Different Levels of Plant Growth Regulators. J. Plant Biochem. Physiol., 6(4).

Vasil, I.K., Vasil, V. 1972. Totipotency and embryogenesis in plant cell and tissue cultures. In Vitro., 8: 117-125

Wetherell, D.F. 1984. Enhanced adventive embryogenesis resulting from plasmolysis of cultured wild carrot cells. Plant Cell Tiss. Organ Cult., 3: 221-227.
Zamir, R., Khalil, S.A., Shah, S.T., Khan, M.S., Ahmad, K., Shahenshah, and Ahmad, N. (2012) Efficient In vitro Regeneration of Sugarcane (Saccharum officinarum L.) from bud explants. Biotechnol. Biotechnol. Equip., 26: 3094-3099.

Zee, S.Y. 1981. Studies on adventive embryo formation in the petiole explants of coriander (Coriandrum sativum). Protoplasma, 107: 21-26. 
